\title{
Seroprevalence of Toxoplasma gondii in small ruminants from four Caribbean islands
}

\author{
Clare M Hamilton ${ }^{1,2}$, Frank Katzer ${ }^{1}$, Elisabeth A Innes ${ }^{1}$ and Patrick J Kelly ${ }^{2 *}$
}

\begin{abstract}
Background: Toxoplasma gondii is a protozoan parasite capable of infecting all warm-blooded animals including livestock. In these animals, the parasite forms cysts in the tissues which may pose a risk to public health if infected meat is consumed undercooked or raw. Little is known of the epidemiology of T. gondii in the Caribbean; therefore, the aim of this study was to determine T. gondii exposure in small ruminants from four Caribbean island nations.

Findings: Sera from 305 sheep and 442 goats from Dominica, Grenada, Montserrat and St. Kitts and Nevis were examined for T. gondii antibodies using an in house ELISA. Reactive antibodies were detected in sheep and goats, respectively, from Dominica (67\%, 37/55; 58\%, 79/136), Grenada (48\%, 40/84; 57\%, 54/94), Montserrat (89\%, 25/28; $80 \%, 25 / 31)$ and St. Kitts and Nevis (57\%, 78/138; 42\%, 76/181).

Conclusions: Our results suggest widespread environmental contamination with $T$. gondii oocysts and that small ruminants could be a potentially important source of $T$. gondii infection if their infected meat is consumed undercooked.
\end{abstract}

Keywords: Toxoplasma gondii, Sheep, Goat, Seroprevalence, Caribbean

\section{Findings \\ Background}

Toxoplasma gondii is a ubiquitous protozoan parasite capable of infecting all warm-blooded animals, including humans [1]. The definitive host, the cat, passes oocysts in its faeces that contaminate the environment where they can remain viable for long periods of time. Intermediate hosts, such as livestock, are infected by ingesting contaminated water or soil and this results in the formation of tissue cysts, containing $T$. gondii, that can remain viable for the lifetime of the host [2]. Although most infections in small ruminants are asymptomatic there can be abortions, foetal mummification, stillbirths and birth of weak lambs/kids [3]. Humans can become infected with $T$. gondii by ingesting tissue cysts from meat, or oocysts from contaminated food or water. Most infections are asymptomatic; however, there can be severe neurological and pulmonary signs in immunosuppressed people. Infections of a foetus during pregnancy can result in retinochoroiditis and neurological abnormalities [4].

\footnotetext{
* Correspondence: pkelly@rossvet.edu.kn

${ }^{2}$ Ross University School of Veterinary Medicine, PO Box 334, Basseterre, St. Kitts, West Indies

Full list of author information is available at the end of the article
}

Small ruminants are a very important source of domestic meat production in the Caribbean [5]. Generally, the Caribbean is a net importer of meat, particularly beef and poultry; however, the demand for sheep and goat meat (both referred to as mutton) is high, and any meat produced locally is consumed by the local population and occasionally by foreign tourists interested in tasting local cuisine [5].

The prevalence of $T$. gondii in food animals is higher in pigs, sheep and goats than in cattle [6,7], and varies worldwide [8]. There are few studies on the prevalence of $T$. gondii in livestock animals in the Caribbean. In Trinidad, a study of animals at slaughter reported $T$. gondii antibodies in $42.9 \%$ of goats and $5.5 \%$ of pigs [9]. In a more recent study, $23.1 \%$ of pigs, $44.1 \%$ of sheep, $42.8 \%$ of goats and $8.4 \%$ of cattle in Grenada and Carriacou were seropositive for $T$. gondii [10].

To provide further data on the epidemiology of T. gondii in small ruminants in the Caribbean, we tested sheep and goats from four different islands for reactive antibodies.

\section{Methods}

Sera used in the study had previously been obtained from mixed-breed sheep and goats on the islands of 
Dominica ( $15^{\circ} 25^{\prime}$ North, 61 $21^{\prime}$ West), Grenada (12 $07^{\prime}$

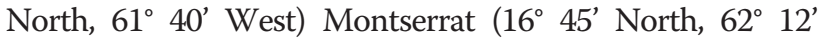
West) and St. Kitts and Nevis ( $17^{\circ} 20^{\prime}$ North, $62^{\circ} 45^{\prime}$ West) between 2007 and 2012 and stored at $-80^{\circ} \mathrm{C}$ [11,12]. All samples were convenience samples collected from healthy, accessible animals on each island, as part of two studies investigating the presence of Rickettsia africae [11] and Ehrlichia ruminantium [12] in domestic ruminants. The animals were free to graze on open pasture during the day and were housed at night in open-air pens. The climate across the Caribbean is typically tropical with little variation in the coastal areas where the sampling sites were located. Ethical approval for the collection of the blood samples was obtained from the Institutional Animal Care and Use Committee, Ross University School of Veterinary Medicine, St. Kitts. Sera were examined for T. gondii antibodies using an in-house ELISA [13], with modifications. In brief, 96-well microtitre plates were coated overnight with $3 \mu \mathrm{g} / \mathrm{ml}$ solubilised RH antigen [14], washed with PBST (PBS with $0.05 \%$ Tween-20) and incubated for $2 \mathrm{~h}$ at $37^{\circ} \mathrm{C}$ after addition of $100 \mu \mathrm{l}$ test or control sera (diluted 1:500 in 1\% BSA in PBST) per well. Following washing, $100 \mu \mathrm{l} \mathrm{HRP-}$ conjugated Protein G (diluted 1:20,000 in 1\% BSA in PBST) was added to each well and plates incubated for $2 \mathrm{~h}$ at $37^{\circ} \mathrm{C}$. ELISAs were developed with TMB and reactions stopped with $2 \mathrm{M} \mathrm{H}_{2} \mathrm{SO}_{4}$ before reading ODs at $450 \mathrm{~nm}$. Control sera were pooled samples of 5 sheep experimentally infected with $T$. gondii, and 5 negative control sheep from the same experiment [15]. For each plate, the cut-off value was calculated as two times the percent positivity of the negative control serum relative to the positive control serum (i.e. [ $2 \mathrm{x}$ (average negative control sera OD/average positive control sera OD)] $\mathrm{x}$ average positive control) [16].

\section{Results}

Antibodies to T. gondii were detected in sheep and goats, respectively, from Dominica (67\%, 37/55; 58\%, 79/136), Grenada (48\%, 40/84; 57\%, 54/94), Montserrat (89\%, 25/ $28 ; 80 \%, 25 / 31)$ and St. Kitts and Nevis (57\%, 78/138; 42\%, 76/181) (Table 1).

\section{Discussion}

Although sample sizes were small, our findings provide the first evidence of $T$. gondii infections in small ruminants from Dominica, Montserrat and St. Kitts and Nevis. Our results, showing that over $40 \%$ of sheep and goats from these islands and Grenada were seropositive for T. gondii, are consistent with previous studies in the Caribbean that reported seroprevalences of $44 \%$ (sheep) and $43 \%$ (goats) in Grenada [10], and 43\% (goats) in Trinidad [9]. The results are also similar to studies in the USA where seroprevalences vary from $60-74 \%$ in sheep [7] and $22-65 \%$ in goats [17], and in Central America where seroprevalences of $44 \%$ in goats [18] and 38\% in sheep [7] have been reported. Similar seroprevalences have also been reported in South America [19]. In our study, the highest seroprevalence was in Montserrat (over 80\%); however, the sample size of animals was the lowest of the 4 island-nations and may therefore not be representative of the true seroprevalence. Also, we have no data on the age of the animals sampled, so it is possible that the animals in Montserrat were older than those sampled on the other islands and therefore more likely to be infected, since seropositivity is known to increase with age [20,21].

With the exception of Grenada, $T$. gondii seroprevalence was higher in sheep than in goats which is a pattern that has previously been reported $[10,20]$ and may be a result of their foraging behaviour and diet selection. Goats are natural browsers tending to eat leaves and twigs from higher bushes and shrubs, whereas sheep are grazers tending to eat short grasses and clovers close to the soil, thus being more likely to encounter oocysts.

Previous studies in Grenada and St. Kitts and Nevis have reported a high $T$. gondii seroprevalence in cats on the islands, indicating that the environment may be contaminated with oocysts shed in their faeces. A survey of cats in Grenada indicated that $31 \%$ of domestic cats, and $28 \%$ of feral cats had antibodies to T. gondii [22]. Studies in St. Kitts and Nevis have demonstrated that $85 \%$ of domestic cats [23] and 74\% of feral cats [24] have antibodies to $T$. gondii. Since ingestion of oocysts from contaminated pasture, feed or water is the main route of transmission for herbivores, the high prevalence reported in the present study suggests that the farms on which the animals were sampled had cats on the premises at some point. Furthermore, previous work has demonstrated that $41 \%$ of feral chickens in Grenada have antibodies to T. gondii, suggesting widespread environmental contamination with oocysts, since chickens are most likely to become infected when feeding on the ground [25].

Table 1 Seroprevalence of Toxoplasma gondii in small ruminants in the Caribbean

\begin{tabular}{|c|c|c|c|c|c|c|}
\hline Island & Sheep tested (n) & Sheep positive (n) & \% Sheep positive & Goats tested (n) & Goats positive (n) & $\%$ Goats positive \\
\hline Dominica & 55 & 37 & 67.3 & 136 & 79 & 58.1 \\
\hline Grenada & 84 & 40 & 47.6 & 94 & 54 & 57.4 \\
\hline Montserrat & 28 & 25 & 89.3 & 31 & 25 & 80.1 \\
\hline St. Kitts and Nevis & 138 & 78 & 56.5 & 181 & 76 & 42.0 \\
\hline TOTAL & 305 & 180 & 59.0 & 442 & 234 & 52.9 \\
\hline
\end{tabular}


It is not known whether the animals sampled in this study were destined for the local food chain; however, it is highly likely since there is no exportation of meat from these islands [26] and there is usually insufficient local production of small ruminant meat to cater for local demand [5]. While we cannot say whether the animals were harbouring tissue cysts, the high seroprevalence indicates high levels of exposure to the parasite, and tissue cysts are known to persist for the lifetime of the host [2]. Therefore, there could be a potential public health risk should the meat be consumed raw or undercooked. In the Caribbean, it is generally common practice to overcook or pressure-cook meat which will reduce the risk of transmission of $T$. gondii; however, the high seroprevalence demonstrated in this study indicates high levels of environmental contamination with oocysts, which could potentially offer an alternative route of transmission through contaminated fruit or vegetables [27] or water [28].

Toxoplasmosis is a significant cause of reproductive failure in sheep and goats, leading to economic losses. Although most sheep and goat owners in the Caribbean are small-scale, low-input producers [5], ruminant meat production still serves as a source of income, and any losses due to abortions may have an impact on their livelihood. There is a paucity of data on $T$. gondii-associated abortions in the Caribbean, likely because they are never reported; however, a longitudinal study on a goat herd in Tobago demonstrated increasing $T$. gondii seroprevalence which was significantly associated with increasing abortion rates [29]. If there is widespread environmental contamination with oocysts on the islands in this study, as indicated by the high seroprevalence, reproductive losses due to toxoplasmosis could potentially be a source of economic losses.

\section{Competing interests}

The authors declare that they have no competing interests.

\section{Authors' contributions}

$\mathrm{CMH}$ performed all serological screening and data analysis, and drafted the manuscript. FK and EAl provided antigenic material and control sera for the ELISAs, and revised the manuscript. PJK conducted original studies which generated serum samples used in the present study, and also revised the manuscript. All authors read and approved the final manuscript.

\section{Acknowledgments \\ This project was funded by Ross University School of Veterinary Medicine and the Moredun Research Institute. We thank the following for assistance with collection of samples: Dr R Thomas (Ministry of Agriculture, Dominica), Dr B Louison (Ministry of Agriculture, Grenada), Dr N Waldron (Ministry of Agriculture, Montserrat), and Drs T. Challenger, P Bartlett and L Henry (Ministry of Agriculture, St Kitts and Nevis).}

\section{Author details}

${ }^{1}$ Moredun Research Institute, Pentlands Science Park, Bush Loan, Edinburgh EH26 OPZ, UK. ${ }^{2}$ Ross University School of Veterinary Medicine, PO Box 334, Basseterre, St. Kitts, West Indies.
Received: 22 July 2014 Accepted: 9 September 2014

Published: 23 September 2014

\section{References}

1. Dubey JP: The history of Toxoplasma gondii-the first 100 years. J Eukaryot Microbiol 2008, 55(6):467-475.

2. Dubey JP, Lindsay DS, Speer CA: Structures of Toxoplasma gondii tachyzoites, bradyzoites, and sporozoites and biology and development of tissue cysts. Clin Microbiol Rev 1998, 11(2):267-299.

3. Diakoua A, Papadopoulos E, Panousis N, Karatzias C, Giadinis N: Toxoplasma gondii and Neospora caninum seroprevalence in dairy sheep and goats mixed stock farming. Vet Parasitol 2013, 198(3-4):387-390.

4. Innes EA: A brief history and overview of Toxoplasma gondii. Zoonoses Public Health 2010, 57(1):1-7.

5. Vokaty S, Torres JG: Meat from small ruminants and public health in the Caribbean. Rev Sci Tech 1997, 16(2):426-432.

6. Dubey JP: Toxoplasmosis in pigs-the last 20 years. Vet Parasitol 2009, 164(2-4):89-103.

7. Dubey JP: Toxoplasmosis in sheep-the last 20 years. Vet Parasitol 2009, 163(1-2):1-14.

8. Tenter AM, Heckeroth AR, Weiss LM: Toxoplasma gondii: from animals to humans. Int J Parasitol 2000, 30(12-13):1217-1258.

9. Adesiyun AA, Cazabon EP: Seroprevalences of brucellosis, Q-fever and toxoplasmosis in slaughter livestock in Trinidad. Rev Elev Med Vet Pays Trop 1996, 49(1):28-30.

10. Chikweto A, Kumthekar S, Tiwari K, Nyack B, Deokar MS, Stratton G, Macpherson CN, Sharma RN, Dubey JP: Seroprevalence of Toxoplasma gondii in pigs, sheep, goats, and cattle from Grenada and Carriacou, West Indies. J Parasitol 2011, 97(5):950-951.

11. Kelly P, Lucas H, Beati L, Yowell C, Mahan S, Dame J: Rickettsia africae in Amblyomma variegatum and domestic ruminants on eight Caribbean islands. J Parasitol 2010, 96(6):1086-1088.

12. Kelly PJ, Lucas H, Yowell C, Beati L, Dame J, Urdaz-Rodriguez J, Mahan S: Ehrlichia ruminantium in Amblyomma variegatum and domestic ruminants in the Caribbean. J Med Entomol 2011, 48(2):485-488.

13. Buxton D, Blewett DA, Trees AJ, McColgan C, Finlayson J: Further studies in the use of monensin in the control of experimental ovine toxoplasmosis. J Comp Pathol 1988, 98(2):225-236.

14. Hughes HP, Van Knapen F, Atkinson HJ, Balfour AH, Lee DL: A new soluble antigen preparation of Toxoplasma gondii and its use in serological diagnosis. Clin Exp Immunol 1982, 49(1):239-246.

15. Katzer F, Canton G, Burrells A, Palarea-Albaladejo J, Horton B, Bartley PM, Pang Y, Chianini F, Innes EA, Benavidas J: Immunization of lambs with the $S 48$ strain of Toxoplasma gondii reduces tissue cyst burden following oral challenge with a complete strain of the parasite. Vet Parasitol. In Press.

16. Semu SM, Peter TF, Mukwedeya D, Barbet AF, Jongejan F, Mahan SM: Antibody responses to MAP $1 B$ and other Cowdria ruminantium antigens are down regulated in cattle challenged with tick-transmitted heartwater. Clin Diagn Lab Immunol 2001, 8(2):388-396.

17. Patton S, Johnson SS, Puckett K: Prevalence of Toxoplasma gondii antibodies in nine populations of dairy goats: compared titers using modified direct agglutination and indirect hemagglutination. $J$ Parasitol 1990, 76(1):74-77.

18. Garcia-Vazquez Z, Rosario-Cruz R, Solorzano-Salgado M: Prevalence of antibodies against Toxoplasma gondii in sheep and goats in 3 states of Mexico. Prev Vet Med 1990, 10(1-2):25-29.

19. Canon-Franco WA, Lopez-Orozco N, Gomez-Marin J, Dubey JP: An overview of seventy years of research (1944-2014) on toxoplasmosis in Colombia, South America. Parasit Vectors 2014, 7:427.

20. Lopes AP, Dubey JP, Neto F, Rodrigues A, Martins T, Rodrigues M, Cardoso L: Seroprevalence of Toxoplasma gondii infection in cattle, sheep, goats and pigs from the North of Portugal for human consumption. Vet Parasitol 2013, 193(1-3):266-269.

21. Katzer F, Brulisauer F, Collantes-Fernandez E, Bartley PM, Burrells A, Gunn G, Maley SW, Cousens C, Innes EA: Increased Toxoplasma gondii positivity relative to age in 125 Scottish sheep flocks; evidence of frequent acquired infection. Vet Res 2011, 42:121.

22. Dubey JP, Lappin MR, Kwok OC, Mofya S, Chikweto A, Baffa A, Doherty D, Shakeri J, Macpherson CN, Sharma RN: Seroprevalence of Toxoplasma gondii and concurrent Bartonella spp., feline immunodeficiency virus, 
and feline leukemia virus infections in cats from Grenada, West Indies. J Parasitol 2009, 95(5):1129-1133.

23. Moura L, Kelly P, Krecek RC, Dubey JP: Seroprevalence of Toxoplasma gondii in cats from St. Kitts, West Indies. J Parasito/ 2007, 93(4):952-953.

24. Dubey JP, Moura L, Majumdar D, Sundar N, Velmurugan GV, Kwok OC, Kelly P, Krecek RC, Su C: Isolation and characterization of viable Toxoplasma gondii isolates revealed possible high frequency of mixed infection in feral cats (Felis domesticus) from St Kitts, West Indies. Parasitology 2009, 136(6):589-594.

25. Dubey JR, Bhaiyat MI, de Allie C, Macpherson CN, Sharma RN, Sreekumar C, Vianna MC, Shen SK, Kwok OC, Miska KB, Hill DE, Lehmann T: Isolation, tissue distribution, and molecular characterization of Toxoplasma gondii from chickens in Grenada, West Indies. J Parasitol 2005, 91(3):557-560.

26. FAO Statistical Yearbook 2014: Latin America and the Caribbean Food and Agriculture. Santiago: FAO; 2014:2014.

27. Kniel KE, Lindsay DS, Sumner SS, Hackney CR, Pierson MD, Dubey JP: Examination of attachment and survival of Toxoplasma gondii oocysts on raspberries and blueberries. J Parasitol 2002, 88(4):790-793.

28. Bowie WR, King AS, Werker DH, Isaac-Renton JL, Bell A, Eng SB, Marion SA Outbreak of toxoplasmosis associated with municipal drinking water, the BC Toxoplasma Investigation Team. Lancet 1997, 350(9072):173-177.

29. Borde G, Lowhar G, Adesiyun AA: Toxoplasma gondii and Chlamydophila abortus in caprine abortions in Tobago: a sero-epidemiological study. $J$ Vet Med B Infect Dis Vet Public Health 2006, 53(4):188-193.

doi:10.1186/1756-3305-7-449

Cite this article as: Hamilton et al: Seroprevalence of Toxoplasma gondii in small ruminants from four Caribbean islands. Parasites \& Vectors.

2014 7:449

\section{Submit your next manuscript to BioMed Central and take full advantage of:}

- Convenient online submission

- Thorough peer review

- No space constraints or color figure charges

- Immediate publication on acceptance

- Inclusion in PubMed, CAS, Scopus and Google Scholar

- Research which is freely available for redistribution 